\title{
Potassium nutrition in the first and second ratoon sugarcane grown in an Oxisol by a conservationist system
}

\author{
Rilner Alves Flores ${ }^{*}$, Renato de Mello Prado², Márcio Alexandre Pancelli², Hilário Júnior Almeida ${ }^{2}$, \\ Leandro Rosatto Moda², Bernardo Melo Montes Nogueira Borges ${ }^{2}$, and Jonas Pereira de Souza Junior ${ }^{2}$
}

\begin{abstract}
The presence of mulch on the soil surface after the mechanical harvesting of sugarcane (Saccharum officinarum L.) enhances the cycling of nutrients, especially K, which can decrease $\mathrm{K}$ fertilizer recommendations for the crop. The aim of this study was to evaluate the effect of $\mathrm{K}$ addition to an Oxisol, with an initial concentration $0.07 \mathrm{cmol}_{\mathrm{c}} \mathrm{K} \mathrm{kg}^{-1}$, in first and second ratoon (no-till) sugarcane cultures by a conservationist system, i.e. rational use of fertilizers, use of alternative inputs and especially the maintenance of residues in soil that was previously burned to facilitate cutting. The following $\mathrm{K}$ doses were tested: $0,32.5,65,130$, and $195 \mathrm{~kg} \mathrm{~K}_{2} \mathrm{O}$ ha $^{-1}$, arranged in a randomized block design with five replicates. Potassium content in the soil and in the plant, as well as the yield and the quality of stalks were evaluated. Soil K application increased $\mathrm{K}$ concentration in soil and plant, and was reflected in the production of stalks, with higher production $(87.5$ and $107.5 \mathrm{t}$ $\mathrm{ha}^{-1}$ ) with the use of 120 and $123 \mathrm{~kg} \mathrm{~K}_{2} \mathrm{O} \mathrm{ha}{ }^{-1}$ in first and second ratoon sugarcane, respectively. At the first $2 \mathrm{yr}$ it was not possible to reduce the $\mathrm{K}$ fertilization in ratoon. Therefore, with the introduction of the conservationist system there was an increase $\left(20 \mathrm{tha}^{-1}\right)$ at the second ratoon regarding the first one with the same applied rate.
\end{abstract}

Key words: Plant nutrition, residues covering, Saccharum officinarum.

\section{INTRODUCTION}

The harvesting of sugarcane (Saccharum officinarum L.), without crop residues, leaves on the ground surface a high amount of DM, between 10 to $20 \mathrm{tha}^{-1}$ (Trivelin et al., 1995) that increases levels of organic matter and improves soil fertility (Mendonza et al., 2000), contributing to yield increase of sugarcane (Ball-Coelho et al., 1993). The residues decomposition releases nutrients to the soil, especially $\mathrm{K}$, about $93 \%$ of the amount initially present in residues (Oliveira et al., 1999).

In tropical soils usually with scarce $\mathrm{K}$ availability, fertilization with this nutrient should induce positive responses in sugarcane, since $\mathrm{K}$ is the nutrient more extracted by the culture, mainly by ratoon (stubble) (Korndörfer and Oliveira, 2005). In addition, low levels of available $\mathrm{K}$ in the soil contribute to reduce sugarcane longevity (Schultz et al., 2010), therefore, is considered an important element in restoring the productivity of sugarcane ratoon (Weber et al., 2002).

So, it is clear the importance of $\mathrm{K}$ for sugarcane

${ }^{1}$ Universidade Federal de Goiás, Campus Samambaia, Escola de Agronomia, Rodovia Goiânia/Nova Veneza, km 0, Caixa Postal 131, CEP 74690-900, Goiânia, Goiás, Brasil.

"Corresponding author (rilner1@hotmail.com).

${ }^{2}$ Universidade Estadual Paulista UNESP, Faculdade de Ciências Agrárias e Veterinárias, Departamento de Solos e Adubos, Jaboticabal, São Paulo, Brasil.

Received: 29 July 2013.

Accepted: 28 November 2013.

doi:10.4067/S0718-58392014000100013 ratoon, i.e. roots that remain in the field after cutting the crop. However, there are few studies in the literature about fertilization with this nutrient in ratoon under conservation system (Dantas Neto et al., 2006; Silva, 2010; Pancelli, 2011). Therefore, cultivation of sugarcane in a conservation system increases residues amount on soil surface, improving the cycling of nutrients, especially $\mathrm{K}$, making it possible to reduce the recommendation of this nutrient for the culture.

This study aimed to evaluate the effect of $\mathrm{K}$ on first and second ratoon sugarcane in an Oxisol under conservation system.

\section{MATERIALS AND METHODS}

The experiment began the first week of April 2010; the cycle was the first ratoon since this date until the end of March 2011, when harvested. The second cycle of ratoon was the first week of July 2011 until harvest in late June 2012. Figure 1 shows the climatic data during a period of growth in the first and second ratoon crop of sugarcane in Jaboticabal, São Paulo, Brazil.

The experiment was carried out in a farm "Santo

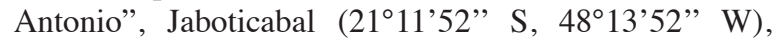
São Paulo, Brazil. The sugarcane variety used in the experiment was 'CTC 05', a high yielding, highly demanding of fertile soils, rust resistant variety, cultivated in a typical dystroferric red latosol (Oxisol) showing a very clayish texture (EMBRAPA, 2006), bulk density of the soil $1.3 \mathrm{~g} \mathrm{dm}^{-3}$. 

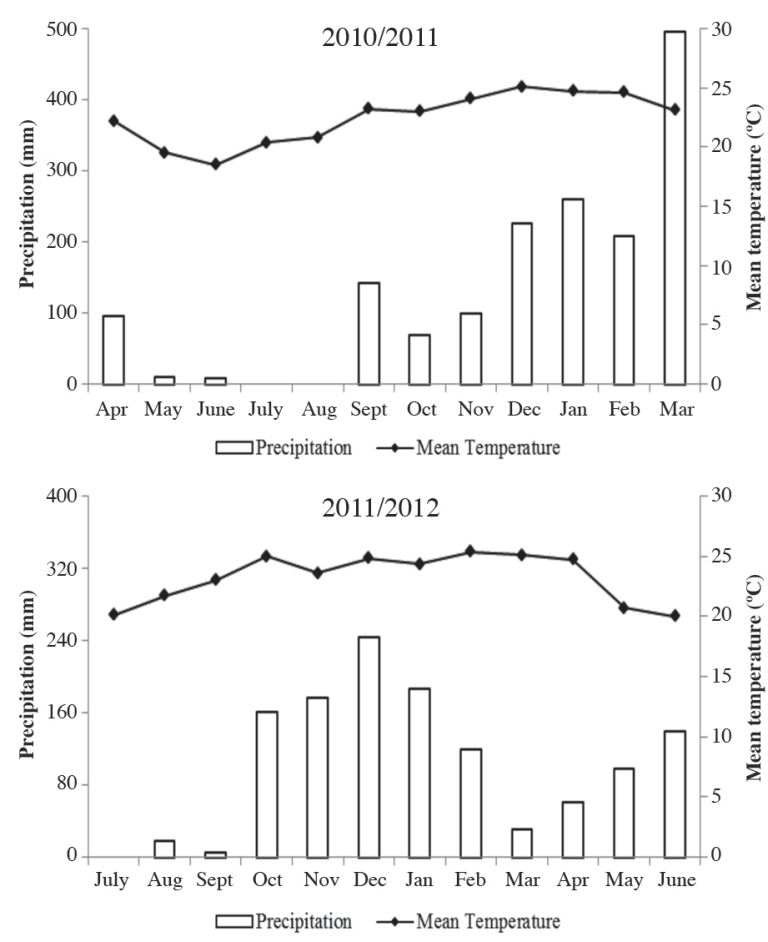

Figure 1. Pluviometric indexes associated with the period of growth during the first and second ratoon sugarcane in Jaboticabal, São Paulo.

Before starting the experiment, 15 soil sub-samples were taken with an auger to obtain a composite soil sample. Samples were taken from 0-20 cm depth. These samples were used to chemical analysis of soil to evaluate their fertility levels in two growing seasons (2010/2011 and 2011/2012). These chemical analyses were conducted according to procedures described by Raij et al. (2001). Results of chemical analysis of soil were: $\mathrm{pH}$ : 5.0 and 5.2, 24 and $29 \mathrm{~g} \mathrm{OM} \mathrm{kg}^{-1}, \mathrm{P}$ (resin): 15 and $18 \mathrm{mg} \mathrm{kg}^{-1}$, 0.07 and $0.05 \mathrm{cmol}_{\mathrm{c}} \mathrm{K} \mathrm{kg}^{-1}, 3.0$ and $4.0 \mathrm{cmol}_{\mathrm{c}} \mathrm{Ca} \mathrm{kg}^{-1}, 1.6$ and $2.0 \mathrm{cmol}_{\mathrm{c}} \mathrm{Mg} \mathrm{kg}^{-1}, \mathrm{H}+\mathrm{Al}: 3.8$ and $3.4 \mathrm{cmol}_{\mathrm{c}} \mathrm{kg}^{-1}$, sum of bases: 4.7 and $6.0 \mathrm{cmol}_{\mathrm{c}} \mathrm{kg}^{-1}$, CEC (cation exchange capacity): 8.5 and $9.45 \mathrm{cmol}_{\mathrm{c}} \mathrm{kg}^{-1}$, base saturation: 55 and $64 \%$, for years 2010 and 2011, respectively.

At the same time, crop residues were taken from soil surface in both years to evaluate total amounts of nutrients immobilized in residual biomass. Samples were taken from three randomly chosen $1 \mathrm{~m}^{2}$ areas and nutrient chemical evaluation was based on procedures described by Bataglia et al. (1983). The DM of residues covering the first ratoon was $13.9 \mathrm{t} \mathrm{ha}^{-1}$, whereas in the second ratoon it was 18.0 $\mathrm{t} \mathrm{ha}^{-1}$. Chemical analyses of residues from first ratoon and second ratoon showed the following respective results: $\mathrm{N}$ $=3.5$ and $6.5, \mathrm{P}=0.5$ and $0.4, \mathrm{~K}=1.2$ and $0.3 ; \mathrm{Ca}=3.1$ and 2.7, $\mathrm{Mg}=0.7$ and 0.9 , and $\mathrm{S}=1.6$ and $0.7 \mathrm{~g} \mathrm{~kg}^{-1}$.

In both experiments treatments were arranged in the field according to a randomized complete block design with five treatments and five replicates. The referential $\mathrm{K}$ fertilizer dose $\left(130 \mathrm{~kg} \mathrm{~K}_{2} \mathrm{O} \mathrm{ha}^{-1}\right)$ was based on values recommended for the State of São Paulo, having in mind a yield between 80 and $100 \mathrm{tha}^{-1}$. So, $\mathrm{K}$ fertilizer doses were: $0,32.5,65,130$, and $195 \mathrm{~kg} \mathrm{~K}_{2} \mathrm{O} \mathrm{ha}^{-1}$, which corresponded to $0,25,50,100$, and $150 \%$ of the referential dose, that is, $130 \mathrm{~kg} \mathrm{~K}_{2} \mathrm{O}$ ha $^{-1}$. These doses were applied manually side dressed to the sugarcane rows, without incorporation, according to indications by Spironello et al. (1997). Two other nutrients $(\mathrm{P}$ and $\mathrm{N})$ were applied also according to indications by Spironello et al. (1997). The first and second ratoon received a dose of $30 \mathrm{~kg} \mathrm{P}_{2} \mathrm{O}_{5} \mathrm{ha}^{-1}$ and $100 \mathrm{~kg} \mathrm{~N} \mathrm{ha}^{-1}$.

In both experiments, each plot was composed of five $10 \mathrm{~m}$ long rows with a spacing of $1.5 \mathrm{~m}$ between rows. Experimental data were collected only from the three central lines of each plot. Soil samples were collected 6-mo after ratoon plants started to sprout in both experiments. These samples were taken from 10 randomly chosen points next to the three central rows of each plot at depths between 0-20 and $20-40 \mathrm{~cm}$. Exchangeable $\mathrm{K}$ in the soil was determined according to procedure reported by Raij et al. (2001).

To determine plant nutritional status, in both ratoons, leaf +1 samples were collected 8-mo after sugarcane plants had started to sprout. The central nervure of each leaf was removed, according to procedure reported by Raij and Cantarella (1997). After being collected, leaves were decontaminated, dried and ground. Chemical methods for determining nutrient levels in plant tissues were reported by Bataglia et al. (1983).

In both ratoons, 12-mo after ratoon plants had started to sprout, a harvest was conducted to determine number of millable stalks and total production of stalks. From the three central rows of each plot, 10 adjacent stalks were picked to determine the sugarcane technological quality according to procedures described by Consecana (2006), i.e. pol (sucrose) per cent in juice, pol (sucrose) per cent in sugarcane, theoretically recoverable sugar (TRS), reducing sugars (RS), fiber, ${ }^{\circ}$ Brix, and purity.

Accumulated $\mathrm{K}$ was evaluated at both ratoon harvests in aerial part, culms and leaves. After weighing fresh material, $400 \mathrm{~g}$ each fraction were dried at $65^{\circ} \mathrm{C}$ in oven until constant weight. Potassium content of plant tissue was determined according to Bataglia et al. (1983). In addition, total DM, $\mathrm{K}$ content, and accumulated $\mathrm{K}$ trash were evaluated at harvest in covering soil surface.

Data collected were subjected to ANOVA and the $F$ values were calculated. The polynomial regression analysis of all data was performed with the statistical program AgroEstat (Barbosa and Maldonado, 2012).

\section{RESULTS AND DISCUSSION}

The applied doses of $\mathrm{K}$ fertilizer increased soil exchangeable $K$ content at depths between 0 and $20 \mathrm{~cm}$ as determined in soil samples taken in both ratoons 6-mo of age. Exchangeable K levels in the first and second ratoons reached values of 0.1 and $0.3 \mathrm{cmol}_{\mathrm{c}} \mathrm{kg}^{-1}$, respectively, when the highest dose of $\mathrm{K}$ fertilizer (195 $\left.\mathrm{kg} \mathrm{K}_{2} \mathrm{O} \mathrm{ha}^{-1}\right)$ was used (Figure 2a). 
It was also observed that in the first ratoon, the application of $\mathrm{K}$ fertilizer had no significant effect on soil $\mathrm{K}$ content at depths $0.2-0.4 \mathrm{~m}$, presenting an average concentration of $0.05 \mathrm{cmol}_{\mathrm{c}} \mathrm{kg}^{-1}$ (Figure 2b). But at the second ratoon, the application of $\mathrm{K}$ fertilizer caused increments with linear adjustment in soil $\mathrm{K}$ content at depths $20-40 \mathrm{~cm}$, reaching $0.07 \mathrm{cmol}_{\mathrm{c}} \mathrm{kg}^{-1}$ with the highest nutrient rate (Figure 2b). Results are similar to those reported by Silva (2010) and Flores et al. (2012).

The $\mathrm{K}$ level found in first ratoon soil was considered low. This is thought to be in part due to leaching of $\mathrm{K}$ to lower soil layers and, at the same time, to K uptake by sugarcane plants since this is the most consumed element by plants of that species and soil samples were taken 6-mo after ratoon plants had started to sprout. According to Coelho and Verlengia (1973), approximately 50\% of total $\mathrm{K}$ absorbed during the vegetative phase of the plant is absorbed when plants are between 5- and 9-mo of age with a strong influence by the amount of rain (Figure 1) and soil conditions.

The soil application of $\mathrm{K}$ fertilizer affected $\mathrm{K}$ content in leaf +1 in both ratoons, promoting linear increments (13.6 and $9.1 \mathrm{~g} \mathrm{~kg}^{-1}$ ) as the $\mathrm{K}$ fertilizer increased from 0 to $195 \mathrm{~kg} \mathrm{~K}_{2} \mathrm{O}$ ha $^{-1}$, respectively (Figure 3). Similar results were reported by Spironello et al. (1986) for analysis performed in leaf +3 and by Silva (2010) and Pancelli (2011) in leaf +1 .
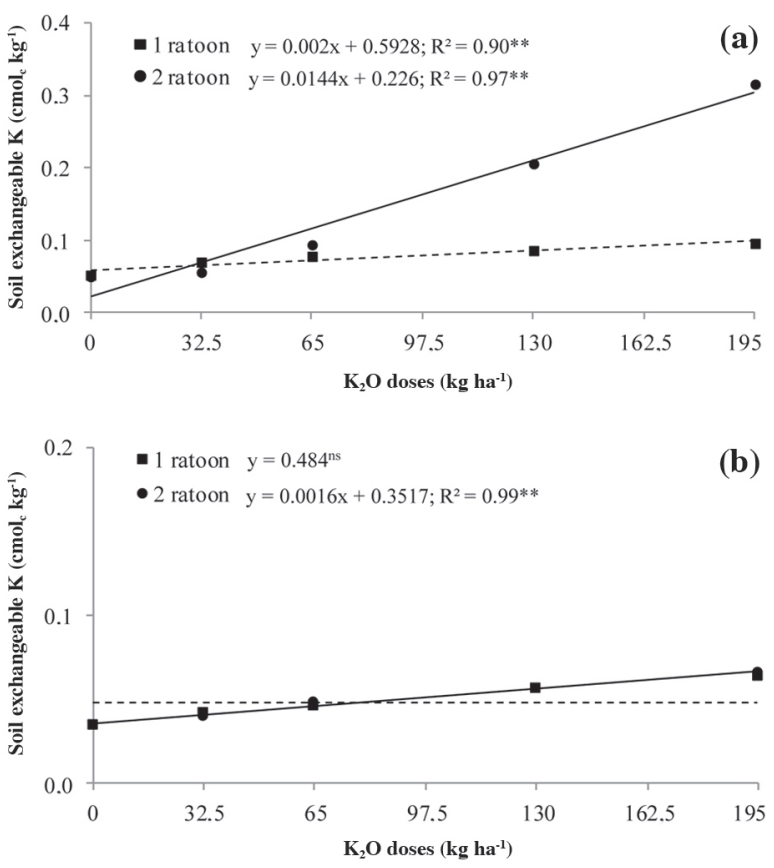

ns: Non significant.

**Significant at $1 \%$ level of probability.

Figure 2. Effect of $\mathbf{K}$-fertilizer dose on the exchangeable level of $\mathbf{K}$ in soil at depths between 0 and $20 \mathrm{~cm}$ (a) and between 20 and $40 \mathrm{~cm}$ (b) 6-mo of age on the first and second ratoon sugarcane.

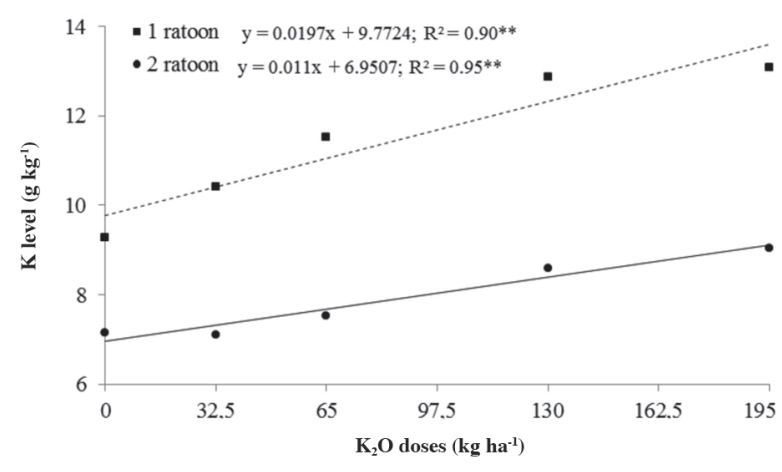

*Significant at $1 \%$ level of probability.

Figure 3. Effects of $\mathrm{K}$-fertilizer dose on the leaf $+1 \mathrm{~K}$ content 8-mo after the budding on the first and second ratoon sugarcane.

The soil $\mathrm{K}$ fertilization did not modify the content of other nutrients analyzed in first and second ratoons. In the first ratoon, levels of nutrients $\mathrm{N}, \mathrm{P}, \mathrm{Ca}, \mathrm{Mg}, \mathrm{S}, \mathrm{B}$, $\mathrm{Cu}, \mathrm{Fe}, \mathrm{Mn}$, and $\mathrm{Zn}$ in leaf +1 were $14.3,1.7,3.5,1.8$, $2.1 \mathrm{~g} \mathrm{~kg}^{-1}, 8,5,108,68$, and $14 \mathrm{mg} \mathrm{kg}^{-1}$, respectively. According to Raij (2011), values found for $\mathrm{N}, \mathrm{B}, \mathrm{Cu}$, and $\mathrm{Zn}$ are low -adequate levels of these nutrients being, respectively, $18-25 \mathrm{~g} \mathrm{~kg}^{-1}, 10-30 \mathrm{mg} \mathrm{kg}^{-1}, 6-16 \mathrm{mg} \mathrm{kg}^{-1}$, and $25-100 \mathrm{mg} \mathrm{kg}^{-1}$, whereas values found for the other nutrients were considered adequate. In the second ratoon, mean values of $\mathrm{N}, \mathrm{P}, \mathrm{Ca}, \mathrm{Mg}, \mathrm{S}, \mathrm{B}, \mathrm{Cu}, \mathrm{Fe}, \mathrm{Mn}$, and $\mathrm{Zn}$ were $17.0,2.5,4.1,1.5,1.1 \mathrm{~g} \mathrm{~kg}^{-1}, 15,4,108,79$, and $10 \mathrm{mg} \mathrm{kg}^{-1}$, respectively. According Raij (2011), values found for $\mathrm{N}, \mathrm{S}$, and $\mathrm{Cu}$ are considered low - adequate levels of these nutrients being $18-25 \mathrm{~g} \mathrm{~kg}^{-1}, 1.5-3.0 \mathrm{~g} \mathrm{~kg}^{-1}$, and 6-16 mg kg${ }^{-1}$, respectively, whereas values found for other nutrients are adequate. According to Raij (2011), K values found in first ratoon are adequate $\left(10-16 \mathrm{~g} \mathrm{~kg}^{-1}\right)$, however, in plots without $\mathrm{K}$ fertilizer (control), $\mathrm{K}$ value was $9.3 \mathrm{~g} \mathrm{~kg}^{-1}$. However, for the second ratoon, values of $\mathrm{K}$ level in leaf +1 are considered low $\left(<10 \mathrm{~g} \mathrm{~kg}^{-1}\right)$. This can occur because high production crops may have a dilution effect on the nutrient content, i.e. as the crop develops nutrient concentration is lower compared to less developed plants (Jarrell and Beverly, 1981). Differences between these results and those reported in literature can be attributed to soil and climatic conditions as well as genetic factor.

Potassium accumulation in leaf tissue at 12 -mo of age in both ratoons was significantly influenced by doses of K-fertilizer applied to the soil (Figure 4). Potassium level in stalk (Figure 4a), leaves (Figure 4b), and in plant aerial part (Figure 4c) followed a quadratic increase with the $\mathrm{K}_{2} \mathrm{O}$ doses applied to the first ratoon. The highest value of $\mathrm{K}$ in stalks $\left(99.4 \mathrm{~kg} \mathrm{ha}^{-1}\right)$ was caused by the dose $164 \mathrm{~kg} \mathrm{~K}_{2} \mathrm{O} \mathrm{ha}^{-1}$; in leaves $\left(88.5 \mathrm{~kg} \mathrm{ha}^{-1}\right)$ by $110 \mathrm{~kg}$ $\mathrm{K}_{2} \mathrm{O} \mathrm{ha}^{-1}$, and in plant aerial part $\left(184.8 \mathrm{~kg} \mathrm{ha}^{-1}\right)$ by 127 $\mathrm{kg} \mathrm{K}_{2} \mathrm{O} \mathrm{ha}^{-1}$. In the second ratoon, quadratic increments of $\mathrm{K}$ were observed in stalks (Figure 4a) and in the aboveground plant part (Figure 4c). The highest value of 

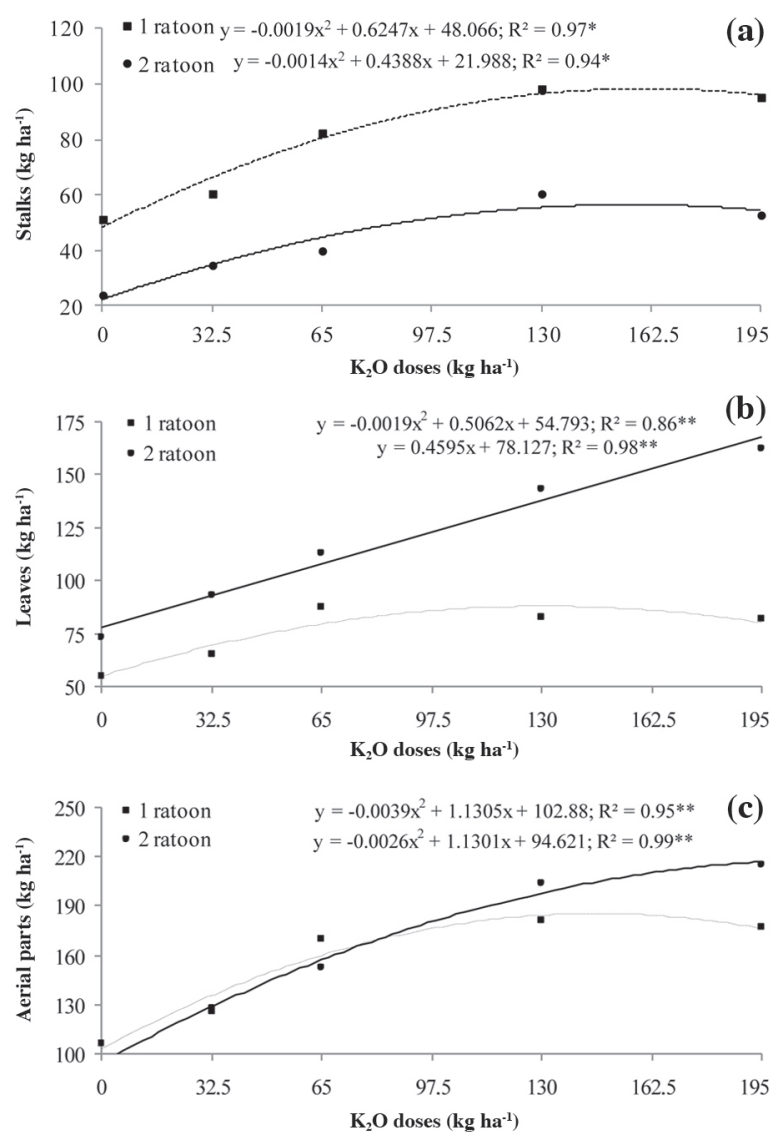

$* *$, *Significant at 5 and $1 \%$ levels of probability, respectively.

Figure 4. Effect of K-fertilizer dose on the accumulation of $K$ in stalks (a), leaves (b), and plant aerial parts (c) 12-mo after the budding on the first and second ratoon sugarcane.

$\mathrm{K}$ in stalks $\left(56.4 \mathrm{~kg} \mathrm{ha}^{-1}\right)$ was caused by the dose of 156 $\mathrm{kg} \mathrm{K}_{2} \mathrm{O}$ ha $^{-1}$ and in the aboveground plant part (216.1 $\mathrm{kg} \mathrm{ha}^{-1}$ ) by $195 \mathrm{~kg} \mathrm{~K}_{2} \mathrm{O} \mathrm{ha}^{-1}$. When the highest dose of $\mathrm{K}_{2} \mathrm{O}\left(195 \mathrm{~kg} \mathrm{ha}^{-1}\right)$ was applied, $\mathrm{K}$ levels in stalk, leaves, and plant aerial part were $84.3,154.3$, and $238.6 \mathrm{~kg} \mathrm{~K}$ $\mathrm{ha}^{-1}$, respectively. However, linear increments of $\mathrm{K}$ were observed in leaves (Figure 4b). The highest value of $\mathrm{K}$ in leaves $\left(167.7 \mathrm{~kg} \mathrm{ha}^{-1}\right)$ was caused by $195 \mathrm{~kg} \mathrm{~K}_{2} \mathrm{O} \mathrm{ha}^{-1}$.

The soil $\mathrm{K}$ application had no significant effect on the concentration of this nutrient in straw covering soil surface after harvest in both cycles. In the first and second ratoon the amount of $\mathrm{K}$ present in the straw was 42.5 and $8.2 \mathrm{~kg} \mathrm{~K}_{2} \mathrm{O}$ ha $^{-1}$, respectively.

Silva (2010) reported linear increments in contents and $\mathrm{K}$ accumulated in both leaves and stalks of ratoon as results of $\mathrm{K}_{2} \mathrm{O}$ doses applied to the soil. Spironello et al. (1986) report similar results. They also verified positive and significant correlations between $\mathrm{K}$ levels in leaves and productivity in six out of eight trials.

The soil application of $\mathrm{K}$ fertilizer affected stalk production, in both ratoons, promoting quadratic increase in first and second ratoons, reaching 87.5 and $107.5 \mathrm{t} \mathrm{ha}^{-1}$

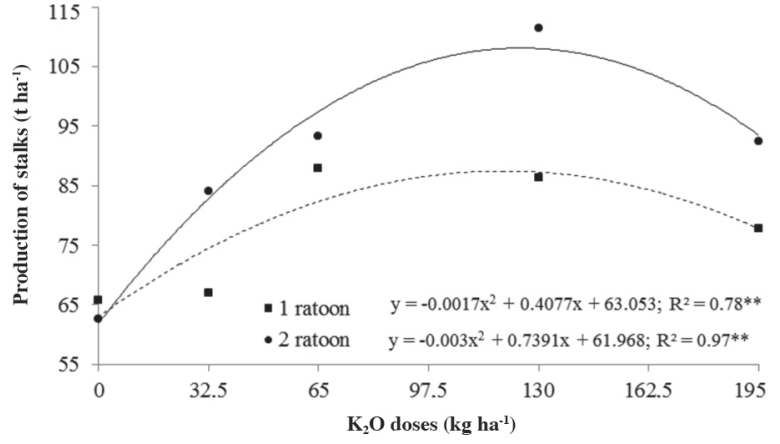

**Significant at the $1 \%$ level of probability.

Figure 5. Effects of K-fertilizer dose on stalk production 12-mo after the budding on the first and second ratoon sugarcane.

with 120 and $123 \mathrm{~kg} \mathrm{~K}_{2} \mathrm{O} \mathrm{ha}^{-1}$, respectively (Figure 5).

The maximum stalk yield in both ratoons was associated with the highest $\mathrm{K}$ concentration in the leaf +1 , that is, $12.2 \mathrm{~g} \mathrm{~kg}^{-1}$ in first ratoon and $9.4 \mathrm{~g} \mathrm{~kg}^{-1}$ in second ratoon, brought about by the fertilizer rate of 120 and $123 \mathrm{~kg} \mathrm{~K}_{2} \mathrm{O} \mathrm{ha}{ }^{-1}$, respectively (Figure 3 ). The values found for $\mathrm{K}$ concentration in leaf +1 in the first ratoon are considered adequate by Raij (2011), that is, between 10 and $16 \mathrm{~g} \mathrm{~kg}^{-1}$; however, in a second ratoon, values found for $\mathrm{K}$ concentration were very close to those considered appropriate $\left(9.4 \mathrm{~g} \mathrm{~kg}^{-1}\right)$, although these values are valid for a harvest system in which sugarcane residues are previously destroyed by fire.

Silva (2010) also reported that the highest stalk yield in a harvest system without previous burning of residues $\left(119.5 \mathrm{t} \mathrm{ha}^{-1}\right)$ was associated with the increment of $\mathrm{K}$ level in leaf $+1\left(50.9 \mathrm{~g} \mathrm{~kg}^{-1}\right)$, which resulted from the highest $\mathrm{K}$ fertilizer dose $\left(195 \mathrm{~kg} \mathrm{~K}_{2} \mathrm{O} \mathrm{ha}^{-1}\right)$.

These results are an indication of the importance of providing ratoon sugarcane plants with adequate nutrient levels, especially $\mathrm{K}$, to have high stalk yields. Pancelli (2011) verified that the highest yield of $127 \mathrm{t} \mathrm{ha}^{-1}$ resulted from the application of $147 \mathrm{~kg} \mathrm{~K}_{2} \mathrm{O} \mathrm{ha}^{-1}$ when leaves showed a $\mathrm{K}$ concentration of $9.3 \mathrm{~g} \mathrm{~kg}^{-1}$.

The beneficial effect of $K$ on productivity of sugarcane cultivated in a harvest system without elimination of residues by fire is reported in the literature. Rossetto et al. (2004) reported significant effects of K in seven out of ten evaluations in which $\mathrm{K}$ was applied to ratoon sugarcane plants, since $\mathrm{K}$ is the nutrient more extracted by the crop, mainly by ratoon (Korndörfer and Oliveira, 2005). In most of their results productivity increased linearly with $\mathrm{K}_{2} \mathrm{O}$ doses only in second or third ratoon. Uchôa et al. (2009) reported quadratic adjustments between $\mathrm{K}_{2} \mathrm{O}$ doses and stalk productivity. According to these authors, $\mathrm{K}_{2} \mathrm{O}$ dose with maximum economic effect was between 94 and $165 \mathrm{~kg} \mathrm{ha}^{-1}$. It is important to remember that the optimum economical yield depends of changing economic factors (prices of products and inputs), therefore they may change year to year. 
Spironello et al. (1986) also observed positive effects of $\mathrm{K}$ fertilization of ratoon sugarcane plants on $\mathrm{K}$ level in leaves and positive correlations between $\mathrm{K}$ level in leaves and stalk productivity in six out of eight trials.

Shukla et al. (2009) reported that $66 \mathrm{~kg} \mathrm{~K}_{2} \mathrm{O}$ ha $^{-1}$ was responsible for the highest production of ratoon sugarcane plants (74.1 t ha-1). Kumar et al. (2007), working with ratoon sugarcane plants in a clayey soil, also observed that the highest yield $\left(88 \mathrm{t} \mathrm{ha}^{-1}\right)$ resulted from $66 \mathrm{~kg} \mathrm{~K}_{2} \mathrm{O}$ ha $^{-1}$.

The application of $\mathrm{K}$ fertilizer in first ratoon, promoted increase only in some restricted quality parameters, as in ${ }^{\circ}$ Brix $\left(y=0.00007 x^{2}+0.0133 x+15.412, R^{2}=0.66^{*}\right)$, and in theoretically recoverable sugar (TRS) $\left(\mathrm{kg} \mathrm{t}^{-1}\right)$ $\left(\mathrm{y}=-0.0006 \mathrm{x}^{2}+0.1297 \mathrm{x}+114.49, \mathrm{R}^{2}=0.74 * *\right)$ and in TRS $\left(\mathrm{t} \mathrm{ha}^{-1}\right)\left(\mathrm{y}=-0.0003 \mathrm{x}^{2}+0.0596 \mathrm{x}+7.139, \mathrm{R}^{2}=\right.$ $\left.0.86^{* *}\right)$. However, for the second ratoon there was a significant increase only for TRS $\left(\mathrm{t} \mathrm{ha} \mathrm{a}^{-1}\right)\left(\mathrm{y}=-0.0005 \mathrm{x}^{2}\right.$ $\left.+0.1218 \mathrm{x}+9.0694, \mathrm{R}^{2}=0.96^{* *}\right)$. But, soil application of $\mathrm{K}$ fertilizer did not affect other quality parameters in first ratoon, with mean values of 85.7, 11.6, 13, 0.6 and $9.8 \%$ for purity, sugarcane pol, juice pol, reducing sugars, and fiber, respectively; and also to the second sugarcane ratoon: $19.5,17.9,91.4,11.6,15.2 \%$ and $150.7\left(\mathrm{~kg} \mathrm{ha}^{-1}\right)$ of ${ }^{\circ}$ Brix, juice pol, purity, fiber, sugarcane pol, and ATR, respectively.

The effect of $\mathrm{K}$ fertilization on quality of sugarcane juice is ambiguous, some authors reported that the addition of $\mathrm{K}$ to the soil does not significantly affect the technological characteristics of sugarcane (Uchôa et al., 2009; Silva, 2010), and others indicate significant effects of $\mathrm{K}$ fertilizer on the technological characteristics of sugarcane (Orlando Filho et al., 1993; Silva, 2010). Since it is not possible to generalize, it is necessary to generate experience to $\mathrm{K}$ managing for each sugarcane region.

\section{CONCLUSIONS}

The application of $\mathrm{K}$ fertilizer on sugarcane ratoon production under conservationist system increases the soil $\mathrm{K}$ content promoting an increase in its availability, reflected in higher stalk yield at the two evaluated ratoon, improving crop quality with increase in theoretically recoverable sugar $\left(\mathrm{t} \mathrm{ha}^{-1}\right)$.

After $2 \mathrm{yr}$ evaluation it was not possible to reduce the fertilizer recommendation for ratoon sugarcane plants, since the maximum productivities were reached with doses close to those recommended for the harvest system in which residues are burned. However, with the introduction of a conservationist system there was an increase of stalk yield of $20 \mathrm{t} \mathrm{ha}^{-1}$ in the second ratoon compared to the first using the same $\mathrm{K}$ rate $\left(130 \mathrm{~kg} \mathrm{ha}^{-1}\right)$ applied to soil.

\section{LITERATURE CITED}

Ball-Coelho, B., H. Tiessen, J.W.B. Stewart, I.H. Salcedo, and E.V.S.B. Sampaio. 1993. Residue management effects on sugarcane yield and soil properties in Northeastern Brazil. Agronomy Journal 85:1004-1008.

Barbosa, J.C., e W. Maldonado Jr. 2012. AgroEstat - Sistema de análises estatísticas de ensaios agronômicos, Versão 1.0. Universidade Estadual Paulista UNESP, Jaboticabal, Brasil

Bataglia, O.C., A.M.C. Furlani, J.P.F. Teixeira, P.R. Furlani, e J.R. Gallo. 1983. Métodos de análise química de plantas. 48 p. Instituto Agronômico, Campinas, Brasil.

Coelho, F.S., e F. Verlengia. 1973. Fertilidade do solo. 384 p. $2^{\circ}$ ed. Instituto Campineiro de Ensino Agrícola, Campinas, Brasil.

Consecana. 2006. Manual de instruções. 110 p. Conselho dos Produtores de Cana-de-Açúcar, Açúcar e Álcool do Estado de São Paulo (CONSECANA), Piracicaba, Brasil.

Dantas Neto, J., J.L.C. Figueiredo, C.H.A. Farias, H.M. Azevedo, e C.A.V. Azevedo. 2006. Resposta da cana-de-açúcar, primeira soca, a níveis de irrigação e adubação de cobertura. Revista Brasileira de Engenharia Agrícola e Ambiental 10:283-288.

EMBRAPA. 2006. Sistema brasileiro de classificação de solos. 412 p. Empresa Brasileira de Pesquisa Agropecuária (EMBRAPA)SPI, Rio de Janeiro, Brasil.

Flores, R.A., R.M. Prado, L.S. Politi, e T.B.F. Almeida. 2012. Potássio no desenvolvimento inicial da soqueira de cana-crua. Pesquisa Agropecuária Tropical 42:106-111.

Jarrell, W.M., and R.B. Beverly. 1981. The dilution effect in plant nutrition studies. Advances in Agronomy 34:197-224.

Korndörfer, G.H., e L.A. Oliveira. 2005. O potássio na cultura da cana-de-açúcar. p. 469-490. In Yamada, T., e T.L. Roberts (eds.) Potássio na agricultura brasileira. Escola Superior de Agricultura Luiz de Queiroz/Universidade de São Paulo (ESALQ/USP), Piracicaba, São Paulo, Brasil.

Kumar, S., N.S. Rana, R. Chandra, and K. Sandeep. 2007. Effect of phosphorus and potassium doses and their application schedule on yield, juice quality and nutrient use efficiency of sugarcane-ratoon crop sequence. Journal of the Indian Society of Soil Science 55(4):122-142.

Mendonza, H.N.S., E. Lima, L.H.C. Anjos, L.A. Silva, M.B. Ceddia, e M.V.M. Antunes. 2000. Propriedades químicas e biológicas de solo de tabuleiro cultivado com cana-de-açúcar com e sem queima da palhada. Revista Brasileira de Ciência do Solo 24:201-207.

Oliveira, M.W., P.C.O. Trivelin, G.J.C. Gava, e C.P. Penatti. 1999. Degradação da palhada de cana-de-açúcar. Scientia Agrícola 56:803-809.

Orlando Filho, J., T. Muraoka, A.A. Rodella, e R. Rossetto. 1993. Fontes de potássio na adubação da cana-de-açúcar: $\mathrm{KCl}$ e $\mathrm{K}_{2} \mathrm{SO}_{4}$. STAB: Açúcar, Álcool e Subprodutos 11(6):1-10.

Pancelli, M.A. 2011. Nutrição potássica e produção da soqueira de cana-de-açúcar no sistema de cana-crua. 32 p. Dissertação de mestrado. Universidade Estadual Paulista, Faculdade de Ciências Agrárias e Veterinárias, Jaboticabal, São Paulo (em Português).

Raij, B. van. 2011. Fertilidade do solo e manejo de nutrientes. p. 157-171. International Plant Nutrition Institute, Piracicaba, Brasil.

Raij, B. van, J.C. Andrade, H. Cantarella, e J.A. Quaggio. 2001. Análise química para avaliação da fertilidade do solo. 285 p. Instituto Agronômico, Campinas, Brasil.

Raij, B. van, e H. Cantarella. 1997. Outras culturas industriais. p. 233-244. In Raij, B. van, H. Cantarella, J.A. Quaggio, e A.M.C. Furlani (eds.) Recomendações de adubação e calagem para o Estado de São Paulo. Instituto Agronômico, Campinas, Brasil.

Rossetto, R., A. Spironello, H. Cantarella, e J.A. Quaggio. 2004. Calagem para a cana-de-açúcar e sua interação com a adubação potássica. Bragantia 63:105-119.

Schultz, N., E. Lima, M.G. Pereira, e E. Zonta. 2010. Efeito residual da adubação na cana-planta e da adubação nitrogenada e potássica na cana-soca colhidas com e sem a queima da palhada. Revista Brasileira de Ciência do Solo 34:811-820. 
Shukla, S.K., R.L. Yadav, P.N. Singh, and I. Singh. 2009. Potassium nutrition for improving stubble bud sprouting, dry matter partitioning, nutrient uptake and winter initiated sugarcane (Saccharum spp. hybrid complex) ratoon yield. European Journal of Agronomy 30:27-33.

Silva, T.M.R. 2010. Nutrição potássica na primeira soqueira de canade-açúcar cultivada em sistema de colheita sem despalha a fogo. 58 p. Monografia - Universidade Estadual Paulista, Faculdade de Ciências Agrárias e Veterinárias, Jaboticabal, São Paulo (em Português)

Spironello, A., J.R. Gallo, A. Lavorenti, T. Igue, e R. Hiroce. 1986. Efeitos da adubação NPK nos teores de macronutrientes das folhas de cana-de-açúcar (cana-soca). Bragantia 45:377-382.

Spironello, A., B. van. Raij, C.P. Penatti, H. Cantarella, J.L. Morelli, J. Orlando Filho, et al. 1997. Cana-de-açúcar. In Raij, B. van, H. Cantarella, J.A. Quaggio, e A.M.C. Furlani (eds.) Recomendações de adubação e calagem para o Estado de São Paulo. Boletim 100. p. 237-239. Instituto Agronômico, Campinas, Brasil.
Trivelin, P.C.O., R.L. Victoria, e J.C. Rodrigues. 1995. Aproveitamento por soqueira de cana-de-açúcar de final de safra do nitrogênio da aquamônia- ${ }^{15} \mathrm{~N}$ e aplicado ao solo em complemento à vinhaça. Pesquisa Agropecuária Brasileira 30:1375-1385.

Uchôa, S.C.P., H.O. Alves Júnior, J.M.A. Alvez, V.F. Melo, e G.B. Ferreira. 2009. Resposta de seis variedades de cana-de-açúcar a dose de potássio em ecossistema de cerrado em Roraima. Revista Ciência Agronômica 40:505-513.

Weber, H., E. Daros, J.L.C. Zambon, O.T. Ido, e J.D. Barela. 2002. Recuperação da produtividade de soqueiras de cana-de-açúcar com adubação NPK. Scientia Agraria 2:73-77. 